УДК $342.92(477)$

DOI https://doi.org/10.32837/pyuv.v0i2(31).580

\author{
C. А. Федчишин \\ orcid.org/0000-0003-3096-3214 \\ кандидат юридичних наук, доцент, \\ доиент кафедри адміністративного права \\ Національного юридичного університету імені Ярослава Мудрого
}

\title{
ОЦІНЮВАННЯ РЕЗУЛЬТАТІВ СЛУЖБОВОЇ ДІЯЛЬНОСТІ ПОСАДОВИХ ОСІБ ДИПЛОМАТИЧНОЇ СЛУЖБИ УКРАЇНИ: ПРОПОЗИЦЇ̈ ЩОДО ВДОСКОНАЛЕННЯ
}

Постановка проблеми. Невід'ємною складовою частиною реформування дипломатичної служби України $€$ вжиття заходів із метою підвищення iㅣ професіоналізму й ефективності. У зв'язку з цим важливого значення набуває дослідження інституту оцінювання результатів службової діяльності посадових осіб дипломатичної служби, вдосконалення його організації та правового забезпечення. Таке оцінювання дозволяє забезпечити контроль за результативністю, ефективністю та якістю виконання посадовими особами дипломатичної служби поставлених завдань з урахуванням посадових обов'язків, дотримання ними правил етичної поведінки та законодавства у сфері запобігання корупції, що, з одного боку, пов'язується із преміюванням посадових осіб дипломатичної служб і плануванням їхньої кар'єри, створенням передумов для просування по службі, а з іншого сприяє очищенню дипломатичної служби України від непрофесійного і недоброчесного персоналу.

Аналіз досліджень і публікацій. Проблеми оцінювання службової діяльності державних службовців, у т. ч. їх атестації та щорічної оцінки, досліджувалися багатьма науковцями (Ю.П. Битяком, Л.Р. Білою-Тіуновою, Ю.С. Даниленко, С.Е. Зелінським, С.В. Ківаловим, А.В. Кірмачем, В.Р. Кравцем, Н.В. Янюк та ін.). У свою чергу, доводиться констатувати, що оцінюванню службової діяльності у такому виді державної служби, як дипломатична служба присвячена лише незначна кількість наукових праць (Л.В. Заболотної, О.В. Селецького, О.Р. Сторожука та ін.). Жодним чином не применшуючи значного вкладу вчених, слід зауважити, що у сфері оцінювання результатів службової діяльності посадових осіб дипломатичної служби і сьогодні залишається низка дискусійних і невирішених проблем. Більшість праць, у яких досліджувався цей інститут, були підготовлені переважно до прийняття нових законів України «Про державну службу» від 10 грудня 2015 р. та «Про дипломатичну службу» від 07 червня $2018 \mathrm{p}$.

Мета статті полягає в тому, щоб проаналізувати основні особливості оцінювання результатів службової діяльності посадових осіб дипломатичної служби відповідно до чинного законодавства України, внести пропозиції стосовно подальшого вдосконалення організації та правового забезпечення цього інституту.

Виклад основного матеріалу. Насамперед слід звернути увагу на те, що Законом України «Про дипломатичну службу» від 07 червня 2018 р. питання оцінювання результатів службової діяльності посадових осіб дипломатичної служби майже не регулюються. Виняток становить лише ч. 10 ст. 25 Закону, котра передбачає, що черговий дипломатичний ранг дипломатичному службовцю не присвоюється протягом строку застосування до нього дисциплінарного стягнення, а також протягом 6 місяців із дня отримання дипломатичним службовцем негативної оцінки за результатами оцінювання його службової діяльності [1]. Інші особливості оцінювання посадових осіб дипломатичної служби (періодичність і порядок проведення, його наслідки та ін.) можуть бути визначені на підставі норм Закону України «Про державну службу» від 10 грудня 2015 р. [2], постанови Кабінету Міністрів України «Про затвердження Порядку проведення оцінювання результатів службової діяльності державних службовців» від 23 серпня 2017 р. [3] та ін.

Відповідно до ст. 44 Закону «Про державну службу» оцінювання результатів службової діяльності: а) проводиться щороку; б) його метою є визначення якості виконання поставлених завдань, прийняття рішень щодо преміювання, планування кар'єри; в) здійснюється на підставі показників результативності, ефективності та якості, визначених з урахуванням посадових обов'язків державного службовця, а також дотримання ним правил етичної поведінки та вимог законодавства у сфері запобігання корупції, виконання індивідуальної програми професійного розвитку, а також показників, визначених у контракті про проходження державної служби (у разі укладення); г) здійснюється: безпосереднім керівником i керівником самостійного структурного підрозділу (щодо державних службовців, які займають посади державної служби категорій «Б» $\mathrm{i}$ «В»); суб'єктом призначення (щодо державних службовців, котрі займають посади державної служби категорій «A»); г) за результатами оцінювання виставляється негативна, позитивна або відмінна оцінка з її обгрунтуванням [2]. 
Законом України «Про внесення змін до деяких законів України щодо перезавантаження влади" від 19 вересня 2019 р. були змінені наслідки виставлення відмінних і негативних оцінок. Первинна редакція Закону "Про державну службу» передбачала таке: а) у разі отримання державним службовцем негативної оцінки не раніше ніж через 3 місяці проводиться повторне оцінювання результатів службової діяльності (ст. 44); отримання двох підряд негативних оцінок мало наслідком припинення державної служби за ініціативою суб'єкта призначення (ст. 87); б) отримання відмінної оцінки визначалося як підстава для преміювання та переважного просування по державній службі. За сучасних умов наслідки отримання негативної оцінки стали більш жорсткими - у разі отримання державним службовцем негативної оцінки за результатами оцінювання службової діяльності він звільняється із служби відповідно до п. 3 ч. 1 ст. 87 Закону «Про державну службу», із ним розривається контракт про проходження державної служби (у разі укладення). Державні службовці, які отримали відмінні оцінки за результатами оцінювання службової діяльності, підлягають преміюванню відповідно до Закону «Про державну службу» (ст. 44, 87).

Звернемося до результатів оцінювання у дипломатичній службі. Внаслідок оцінювання посадових осіб дипломатичної служби за 2018 р. із-поміж дипломатичних службовців апарату Міністерства закордонних справ України (далі - МЗС України) та закордонних дипломатичних установ (далі ЗДУ) 493 особи (60,6\% ) отримали відмінну оцінку, 314 осіб (38,6\% ) - позитивну і лише 6 осіб $(0,7 \%$ ) негативну. Результати оцінювання адміністративних службовців були схожими за співвідношенням: 143 особи $(55,4 \%)$ отримали «відмінно»; $114(44,2 \%)$ - «позитивно» та лише 1 особа $(0,4 \%)$ «негативно» 1 . Таким чином, внаслідок оцінювання за 2018 р., по-перше, істотного «очищення» дипломатичної служби не відбулося (всього 1 особа з апарату МЗС України і 6 осіб із ЗДУ отримали негативні оцінки); по-друге, виникли підстави для преміювання більше як для половини посадових осіб дипломатичної служби, які оцінювалися.

Аналізуючи результати оцінювання посадових осіб дипломатичної служби за 2018 р. державний секретар МЗС України А.І. Заяць охарактеризував їх такими, що розчарували, адже, за його попередніми оцінками, в дипломатичній службі близько третини персоналу є «баластом», якого слід було б позбутися. Незначну кількість негативних оцінок Державний секретар МЗС України пов'язував із відсутністю принциповості у деяких керівників. Він відзначив недосконалість чинної процедури оцінювання, котра є загальною та не враховує специфіки дипломатичної служби; підкреслив доцільність розробки специфічного оцінювання саме для посадових осіб дипломатичної служби $[10 ; 14]$.

Дипломатична служба вирізняється низкою специфічних особливостей, які повинні бути враховані та відображені у порядку оцінювання результатів службової діяльності (довготермінове відрядження та ротація посадових осіб дипломатичної служби; перебування їх у розпорядженні МЗС України; можливість переведення посадових осіб дипломатичної служби на посади до інших державних органів; проходження працівниками інших органів дипломатичної служби в органах дипломатичної служби та ін.). На нашу думку, існує декілька можливих шляхів вдосконалення законодавства в цій частині. Одним із таких шляхів може стати внесення змін до постанови Кабінету Міністрів України «Про затвердження Порядку проведення оцінювання результатів службової діяльності державних службовців» від 23 серпня 2017 р. (далі - Порядку) та врегулювання в ній у межах окремого розділу особливостей оцінювання результатів службової діяльності посадових осіб дипломатичної служби. Подібний підхід до врегулювання особливостей процедур у дипломатичній службі вже має місце у вітчизняній практиці. Наприклад, особливості проведення конкурсу на зайняття посад дипломатичної служби категорій «Б» та «В» врегульовані окремим розділом у постанові Кабінету Міністрів України «Про затвердження Порядку проведення конкурсу на зайняття посад державної служби» від 25 березня 2016 р.

Якість підзаконного регулювання у сфері оцінювання результатів службової діяльності посадових осіб дипломатичної служби безпосередньо залежить від положень Законів «Про державну службу» та «Про дипломатичну службу», які сьогодні не є досконалими. Зокрема, має місце неузгодженість законодавчих положень у частині юридичних наслідків негативної оцінки. У ч. 6 ст. 39 Закону «Про державну службу» закріплено, що черговий ранг державному службовому не присвоюється протягом 6 місяців із дня отримання ним негативної оцінки за результатами оцінювання службової діяльності. Аналогічна норма міститься у ч. 10 ст. 25 Закону «Про дипломатичну службу» щодо присвоєння дипломатичних рангів: черговий дипломатичний ранг дипломатичному службовцю не присвоюється протягом 6 місяців із дня отримання ним негативної оцінки за результатами оцінювання його службової діяльності. Водночас ч. 6 ст. 44 «Оцінювання результатів службової діяльності» Закону «Про дер-

\footnotetext{
${ }^{1}$ За інформацією, наданою Міністерством закордонних справ України.
} 
жавну службу" передбачає звільнення державного службовця у разі отримання ним негативної оцінки, що не узгоджується із наведеними нормами законів щодо присвоєння рангів державного службовця та дипломатичних рангів.

Крім неврахування особливостей дипломатичної служби, чинний порядок оцінювання результатів службової діяльності відзначається й іншими недоліками. Важливим питанням є суб'єкти, котрі здійснюють оцінювання результатів службової діяльності. Привертає увагу, що сьогодні у такому оцінюванні не беруть участь колегіальні суб'єкти (комісіі). Нещодавно в абз. 2 п. 29 Порядку передбачалося утворення комісіі: «У разі надходження пропозицій стосовно державного секретаря міністерства з негативною оцінкою НАДС утворює комісію для вивчення обгрунтованості негативної оцінки». Проте змінами до Порядку від 05 лютого 2020 р. така вимога комісійного розгляду була скасована.

Таким чином, за чинного механізму істотно зростає роль «однієї особи» та суб'єктивного фактору в оцінюванні, що може перешкоджати об'єктивному розгляду питання та прийняттю рішення. Безумовно, оцінювання, яке проводиться комісією чисельністю, наприклад, у п'ять і більше осіб, порівняно із тим, що проводиться однією-двома особами (безпосереднім керівником і керівником самостійного структурного підрозділу або суб'єктом призначення), більш імовірно буде усестороннім і неупередженим. Колегіальний розгляд сприятиме зменшенню дії негативних психологічних чинників (страху деяких керівників перед звинуваченням у необ'єктивності, бажання завжди бути «добрими» для підлеглих та ін.), підвищить професіоналізм і принциповість у прийнятті рішень.

$\mathrm{y}$ наукових джерелах неодноразово обговорювалися недоліки та переваги одноособового і колегіального оцінювання результатів службової діяльності, вказувалося на доцільність залучення до проведення оцінювання представників громадськості. Зокрема, Ю.С. Даниленко підкреслює, що «будь-яке визначення безпосереднім керівником (для державних службовців категорій «Б», «В») чи суб'єктом призначення (для державних службовців категорії «А») результатів службової діяльності не позбавлене суб'єктивізму, залежно від прихильності до окремих працівників, відмінностей у підходах оцінювання». Вчена пропонувала розширити коло суб'єктів оцінювання результатів службової діяльності державних службовців шляхом залучення представників громадськості, зокрема в особі представників громадських рад [9, с. 8, 121]. Описуючи суб'єктів оцінки державних службовців, С.Е. Зелінський вказує, що «внаслідок залучення різних суб'єктів атестаційна комісія видає найбільш повноцінну, об'єктивну оцінку» $[13$, с. 70$]$.
О.В. Селецький характеризував оцінювання професійної діяльності дипломатичних працівників як один із елементів проходження ними служби. Дослідження проводилося до прийняття нового Закону «Про дипломатичну службу», проте висновки вченого в частині розширення суб'єктів оцінювання видаються актуальними. Науковець пропонував обов'язково залучати незалежних експертів до роботи атестаційних комісій, що, на його думку, «дасть змогу суттєво підвищити ефективність проведення кожної атестації та унеможливить порушення прав і свобод осіб, котрі атестуються, зі сторони роботодавця. У свою чергу, це додатково дозволить запобігти проявам корупції на дипломатичній службі». Крім того, вказувалося, що не було б зайвим запрошувати на засідання атестаційних комісій викладачів освітніх установ, зокрема Дипломатичної академії України при МЗС України, представників громадських організацій і 3MI [16, с. 252].

Аналіз зарубіжного досвіду показує, що іноземними державами вживаються різноманітні заходи, спрямовані на забезпечення професійного й об'єктивного оцінювання службової діяльності дипломатичних службовців відповідно до встановлених критеріїв. Одним із таких заходів можна вважати і колегіальне оцінювання службової діяльності (атестацію) дипломатичних службовців, передбачене законодавством низки іноземних держав. Наприклад, згідно зі ст. 8 Закону Латвійської Республіки «Про дипломатичну та консульську службу» від 10 жовтня 1995 р. атестаційна комісія проводить оцінювання діяльності та результатів діяльності дипломатів, державних службовців і працівників дипломатичної та консульської служби: а) у разі подання ними заявки на участь у внутрішньому конкурсі на нову посаду (місце служби); б) у разі необхідності прийняти рішення про переведення їх із однієї місії в іноземній державі до іншої місії в іноземній державі; в) у разі необхідності прийняття рішення про підвищення дипломатичного рангу. Комісія може визначити й інші підстави для проведення оцінювання [6].

У ст. 6 Закону Литовської Республіки «Про дипломатичну службу» від 29 грудня 1998 р. закріплено, що оціночна комісія оцінюе службову діяльність дипломатів у встановленому міністром закордонних справ порядку, обговорює кандидатури дипломатів, а також відповідність дипломатів посадам, які ними обіймаються або на які їх призначають, питання направлення дипломатів на навчання або стажування до іноземних держав, питання присвоєння дипломатичних рангів, а також надає рекомендації із цих питань міністру закордонних справ [5].

Колегіальне оцінювання службової діяльності (атестація) дипломатичних службовців практикується в Білорусі ( «комісія з атестації, присвоєння 
дипломатичних рангів і класів державним службовцям»), Вірменії («конкурсно-атестаційна комісія»), Молдові («оціночно-конкурсна комісія»), Естонії («атестаційна комісія») та низці інших пострадянських держав.

Звернення до колективних форм має місце при атестації дипломатичних службовців КНР. Закон КНР «Про дипломатичний персонал, що проходить службу за кордоном» від 31 жовтня 2009 р. передбачає, що дипломатичний персонал за кордоном атестується на основі всебічного аналізу моральних якостей, здібностей, старанності, досягнень та чесності у виконанні обов'язків і завдань, а особливо результатів роботи. Результати атестації є основою для зміни посад, рангів і заробітної плати, прийняття рішення про заохочення або професійне навчання (ст. 28) [11, с. 480-481]. Порядок атестації визначається Законом КНР «Про державну службу» від 27 квітня 2005 р. Регулярна атестація державних службовців, які не займають керівну посаду, здійснюється у формі підготовки службовцями річного звіту. Керівники державних службовців з урахуванням колективних думок і оцінок дають пропозиції для затвердження керівником органу або уповноваженою атестаційною комісією. Регулярна атестація службовців керівного складу здійснюється компетентними органами у встановленому порядку [8, с. 408]. Відмінною рисою досвіду КНР є участь дипломатичних службовців у оцінці відповідно до встановленої системи балів як їхніх колег одного рівня, так і керівників [18, с. 31]. До складу атестаційної комісії включаються представники департаменту кадрів і партійного комітету, що $є$ одним із проявів політизації китайської дипломатичної служби [12, с. 259].

На особливу увагу заслуговує досвід оцінювання у Закордонній службі США. Оцінювання працівників Закордонної служби США тісно пов'язується із вирішенням питань стосовноїх просування по службі (Promotion), а за певних умов може стати і підставою відбору працівників для звільнення (Selection out). Окреме місце у процедурі просування по Закордонній службі США відводиться роботі відповідних рад. Просування по Закордонній службі охоплює такі складові частини:

а) консультування (Counseling) - обговорення керівником і підпорядкованим працівником особливостей роботи, очікувань керівника від роботи працівника та його відповідності цим очікуванням. Керівник (особа, що здійснює оцінювання), підпорядкований працівник (працівник, який оцінюється) та рецензент (зазвичай вищестоящий керівник відносно того, хто здійснює оцінювання) повинні письмово підтвердити, що обговорили роботу працівника і визначили вимоги до неї. Керівник і працівник мають задокументувати як мінімум 2 відповідні обговорення; б) оцінювання (Evaluation) - передбачає щорічну підготовку працівником звіту про свою діяльність (Employee Evaluation Report). Частиною такого звіту стає інформація щодо виконання працівником вимог до роботи, які раніше були письмово визначені у взаємодії керівником, цим працівником і рецензентом. Керівник з'ясовує рівень виконання роботи й оцінює їі, заповнюючи відведену для цього секцію бланку (до 400 слів). У другій секції такого самого обсягу керівник оцінює потенціал працівника за основними 6 сферами компетентності (такими як лідерство, менеджмент, міжособова взаємодія, комунікація та іноземні мови, інтелектуальні здібності, змістовні знання). Особливістює те, що керівник має заповнити також секцію під назвою «Сфери для розвитку» ("Areas for improvement»), у якій має вказати як мінімум 1 із 6 сфер компетентності, у якій працівник може досягати кращих результатів. Кожен звіт щодо оцінювання включає рецензію (Review statement), котра зазвичай готується вищестоящим керівником над тим, який здійснює оцінювання, а також іншим службовцем. Після виставлення оцінки та підготовки рецензій працівнику надається 5 днів для написання пояснень i заперечень (Rated Employee Comment Section). Ані керівник, ані рецензент не мають доступу до відповідних пояснень і заперечень працівника;

в) відбір (Selection) - здійснюється радою, вид якої залежить від шляху просування по службі (просування до кар'єрної служби або просування за класами). Радами, які здійснюють відбір, є: а) рада із надання кар'єрного статусу (Commissioning and tenure board) - при просуванні до кар'єрної служби; б) відбіркова рада (Selection board) - при просуванні кар'єрних дипломатів за класами. Процедури діяльності рад є схожими. Зокрема, відповідно до ст. 602 Закону США «Про закордонну службу» від 1980 р. відбіркові комісії (selection boards) можуть надавати рекомендації щодо: 1) підвищення по службі згідно зі ст. 601; 2) призначення премії за результатами діяльності згідно зі ст. 405 (c); 3) відмови у підвищенні в межах класу згідно зі ст. 406 (a); 4) пропозицію строкового призначення згідно зі ст. 607 (b); та 5) вчинення Державним секретарем інших дій, передбачених законодавством. На рівні Закону США «Про закордонну службу» встановлено, що відбіркові комісії повинні включати представників громадськості, серед їхніх членів мають бути жінки та представники груп меншин [4].

Як зазначають дослідники Закордонної служби США Г. Копп і Ч. Джіллеспі, відбіркові комісії (selection boards) аналізують як найкращі, так i найгірші результати діяльності. У разі встановлення, що працівник не зростає професійно й у визначений строк не отримує відповідного підвищення, він може потрапити у число осіб, віді- 
браних для звільнення (так звана система «Up or Out»). Якщо працівник отримує низькі оцінки двічі протягом 5 років різними суб'єктами оцінювання його справа передається на розгляд ради зі стандартів діяльності (Performance standards board). У разі підтвердження цією радою невідповідності роботи працівника встановленим стандартам він звільняється (Retirement based on relative performance) $[17$, с. 216-221]. Таким чином, працівник Закордонної служби США, перш ніж бути звільненим на підстави низької оцінки його діяльності, піддається перевірці не одним колегіальним утворенням (радами), що лише сприяє усесторонньому розгляду й об’єктивному прийняттю рішення.

Що стосується перспектив запровадження комісійного (колегіального) оцінювання посадових осіб дипломатичної служби в Україні, то, на нашу думку, слід врахувати таке. 3 одного боку, необхідно унеможливити зловживання зі сторони керівників, забезпечити об'єктивне оцінювання та прийняття рішень, гарантування прав посадових осіб дипломатичної служби, зміцнення їх мотивації до професійного росту, а з іншого - не створити необгрунтованих ускладнень, які б негативно відзначалися на оперативності процедур. У зв'язку із наведеним вважаємо, що запровадження комісійного оцінювання всіх без винятку посадових осіб дипломатичної служби містить низку ризиків. Насамперед виникає обгрунтоване питання «Чи не буде відповідна комісія перевантажена або ж взагалі заблокована з огляду на щорічність проведення оцінювання?». Ризик перевантаження комісії за умови проведення щорічного оцінювання дійсно великий, а тому навряд чи доцільним є запровадження суцільного колегіального (комісійного) оцінювання всіх посадових осіб дипломатичної служби. На нашу думку, доцільним є запровадження та «зосередження» колегіального (комісійного) розгляду саме на найбільш важливих «ділянках» оцінювання, котрі пов'язані із найбільш серйозними для посадових осіб юридичними наслідками (наприклад, у разі виставлення негативної оцінки, що тягне звільнення зі служби, тощо).

$\mathrm{y}$ цьому сенсі привертає увагу досвід Литви. Згідно зі ст. 22 Закону Литви «Про публічну службу» від 23 квітня 2002 р. оцінювання публічних службовців умовно є двоступеневим: «Наприкінці кожного календарного року прямий начальник публічного службовця або особа, що прийняла публічного службовця на пост, чи уповноважена ним особа оцінюють діяльність (виконання) публічного службовця як бездоганне, добре або незадовільне. У разі, коли діяльність публічного службовця оцінено як бездоганну або незадовільну, публічного службовця оцінює оціночна комісія». Оцінка «бездоганно» $є$ підставою для внесення особі, яка прийняла публічного службовця на посаду, однієї
3 передбачених пропозицій (надати такому службовцю вищий кваліфікаційний клас, перевести його на вищу посаду тощо). За незадовільну оцінку публічного службовця оціночна комісія пропонує особі, котра найняла його на посаду, одне 3 такого: 1) вдосконалити кваліфікацію публічного службовця; 2) надати нижчий кваліфікаційний клас публічному службовцю; 3) перевести кар'єрного службовця на нижчу посаду; 4) звільнити публічного службовця зі служби, якщо оцінка незадовільна два рази підряд [15, с. 437-438].

Як бачимо, за литовської моделі оцінювання публічних службовців має місце поєднання єдиноначальності та колегіальності. Проте колегіальний (комісійний) розгляд відбувається за умови виставлення публічному службовцю не середньої, умовно нейтральної оцінки («добре»), а найвищої («бездоганно») чи найнижчої («незадовільно») оцінок, котрі можуть спричинити найбільш серйозні юридичні наслідки - як позитивні, так і негативні. За такої моделі створюються передумови для відповідального ставлення керівників до виставлення підлеглим щорічних оцінок, створюються перешкоди на шляху упередженості та зловживань, порушення прав службовців. Погоджуємося із Л.Р. Білою-Тіуновою, що литовська модель дійсно має «тенденцію до спрощення процедури оцінювання» [7, с. 299]. На нашу думку, важливо, що таке спрощення відбувається не за рахунок професійного й об'єктивного підходу, гарантування прав службовців. Вважаємо, що використання в Україні відповідного литовського досвіду є одним із можливих шляхів вдосконалення оцінювання посадових осіб дипломатичної служби. Можливим є запровадження додаткового обов'язкового оцінювання комісією лише для тих посадових осіб дипломатичної служби, які за результатами щорічної оцінки відповідними керівниками отримали відмінну або негативну оцінку.

На підставі проведеного аналізу можна зробити такі висновки.

1. Оцінювання результатів службової діяльності є важливим інститутом, від належної організації та правового регулювання якого залежить забезпечення професіоналізму й ефективності дипломатичної служби України. Цей інститут має бути дієвим; забезпечувати постійну конструктивну комунікацію між керівниками та підпорядкованими, контроль за результативністю, ефективністю та якістю виконання поставлених завдань 3 урахуванням посадових обов'язків, дотриманням законодавства у сфері запобігання корупції; сприяти підвищенню професіоналізму й ефективності службової діяльності посадових осіб, зміцненню ïx мотивації до вдосконалення та професійного розвитку. Оцінювання та його результати мають враховуватися та реально впливати на планування кар'єри, створювати передумови для просуван- 
ня по службі, забезпечувати «очищення» дипломатичної служби України від непрофесійного та недоброчесного персоналу.

2. Оцінювання результатів службової діяльності як у державній службі загалом, так і в дипломатичній службі зокрема характеризується низкою проблем, уся сукупність яких не може бути проаналізована у межах однієї статті. Подальший розвиток інституту оцінювання результатів службової діяльності посадових осіб дипломатичної служби пов'язується із усуненням колізій і вдосконаленням Законів «Про державну службу» та «Про дипломатичну службу», внесенням змін до постанови Кабінету Міністрів України «Про затвердження Порядку проведення оцінювання результатів службової діяльності державних службовців» від 23 серпня 2017 р. та врегулюванням в ній у межах окремого розділу особливостей оцінювання результатів службової діяльності посадових осіб дипломатичної служби.

3. Вдосконалення оцінювання результатів службової діяльності посадових осіб дипломатичної служби має відбуватися з урахуванням передового зарубіжного досвіду. Можливим напрямом удосконалення цього інституту може стати запровадження додаткового оцінювання комісією тих посадових осіб дипломатичної служби, які отримали відмінну або негативну оцінки. Комісійний розгляд сприятиме об’єктивному оцінюванню та прийняттю рішень, гарантуванню прав посадових осіб дипломатичної служби, зміцненню їх мотивації до розвитку. Важливе значення має виважений підхід до врегулювання статусу такої комісії, особливостей їі організації з урахуванням специфіки дипломатичної служби, включення до неї представників громадськості. У свою чергу, слід підкреслити, що запровадження комісійного оцінювання у дипломатичній службі не вирішить усіх проблем у цій сфері та має бути доповнене комплексом інших заходів, одним із яких повинен стати перегляд наслідків виставлення тих чи інших оцінок.

\section{Iimepamypa}

1. Про дипломатичну службу : Закон України від 07 червня 2018 р. № 2449-VIII. Офіиійний вісник Украӥни. 2018. № 50. Ст. 1747.

2. Про державну службу : Закон України від 10 грудня 2015 р., № 889-VIII. Офіиійний вісник Украї ни. 2016. № 3. Ст. 149.

3. Про затвердження Порядку проведення оцінювання результатів службової діяльності державних службовців : постанова Кабінету Міністрів України від 23 серпня 2017 р. № 640. Офіиійний вісник України. 2017. № 70. Ст. 2124.

4. Foreign Service Act of 1980, United States of America. URL: https://legcounsel.house.gov/Comps/ Foreign $\%$ 20Service $\% 20$ Act $\% 200 f \% 201980$.pdf (дата звернення: 18.06.2020).

5. Law On Diplomatic Service, The Republic of Lithuania, 29.12.1998. URL: https://e-seimas.lrs.lt/
portal/legalActPrint/lt?jfwid=fhhu5mqh0\&documentId=TAIS.85558\&categor $\mathrm{y}=\mathrm{TAD}$ (дата звернення: 04.06.2020).

6. Law On Diplomatic and Consular Service, The Republic of Latvia, 10.10.1995. URL: http://www.vvc.gov.lv/ export/sites/default/docs/LRTA/Likumi/Diplomatic and_Consular_Service_Law.pdf (дата звернення: 04.06.2020)

7. Біла-Тіунова Л.Р. Службова кар'єра в Україні : монографія. Одеса : Фенікс, 2011. 540 с.

8. Государственная служба в странах основных правовых систем мира : в 2 т. / под ред. А.А. Демина. Москва : Книгодел, 2010. Т. 2. 428 с.

9. Даниленко Ю.С. Оцінювання у державній службі: теорія і правове регулювання : дис. ... канд. юрид. наук. Одеса, 2017. 200 с.

10. Державний секретар МЗС України Андрій Заяць про проблеми та реформи у зовнішньополітичному відомстві. Zn.ua. № 49. 2018. URL: https://dt.ua/international/diplomatichna-sluzhbaukrayini-versiya-2018-297341_.html.

11. Дипломатическая служба зарубежных стран : сборник нормативных правовых актов / сост. Т.А. Занко. Москва : МГИМО-Университет, 2015. 690 с.

12. Дипломатическая служба зарубежных стран : учебник / под ред. А.В. Торкунова, А.Н. Панова. Москва : Аспект Пресс, 2015. 400 с.

13. Зелінський C.Е. Теоретико-методологічні засади комплексного оцінювання державних службовців : монографія. Київ : НАДУ, 2016. 296 с.

14. Інтерв'ю з Державним секретарем МЗС України А.I. Заяцем. Європейська правда. 23.08.2018. URL: https://www.eurointegration.com.ua/interview/ 2018/08/23/7085949/.

15. Публічна служба. Зарубіжний досвід та пропозиції для України / за заг. ред. В.П. Тимощука, А.М. Школика. Київ : Конус-Ю, 2007. 735 с.

16. Селецький О.В. Оцінювання професійної діяльності дипломатичних працівників як один з елементів проходження дипломатичної служби. Право і суспільство. 2013. № 6-2. С. 250-254.

17. Kopp H., Gillespie Ch. Career diplomacy. Life and work in the US Foreign Service. Washington : Georgtown University Press, 2011. $301 \mathrm{p}$.

18. Rana S. Kishan. Asian Diplomacy. The Foreign Ministries of China, India, Japan, Singapore, and Thailand. Washington : Woodrow Wilson Center Press, 2009. 246 p.

\section{Анотація}

Федчищин C. A. Оцінювання результатів службової діяльності посадових осіб дипломатичної служби України: пропозиції щодо вдосконалення. - Стаття.

Стаття присвячена дослідженню оцінювання результатів службової діяльності посадових осіб дипломатичної служби України. Підкреслено, що оцінювання результатів службової діяльності є важливим інститутом, від належної організації та правового регулювання якого залежить забезпечення професіоналізму й ефективності дипломатичної служби України. Проаналізовано сучасний стан правового регулювання оцінювання результатів службової діяльності посадових осіб дипломатичної служби. Звернуто увагу на окремі неузгодженості положень Законів «Про державну службу» та «Про дипломатичну службу». Необхідним є внесення змін до постанови Кабінету Міністрів України «Про затвердження Порядку проведення оцінювання результатів службової діяльності державних службовців» від 23 серпня 2017 р. та врегулювання в ній у межах окремого розділу особливостей оціню- 
вання результатів службової діяльності посадових осіб дипломатичної служби. Підкреслено, що вдосконалення оцінювання результатів службової діяльності посадових осіб дипломатичної служби має відбуватися з урахуванням передового зарубіжного досвіду. Зроблено висновок, що можливим напрямом удосконалення цього інституту може стати запровадження додаткового оцінювання комісією тих посадових осіб дипломатичної служби, які отримали відмінну або негативну оцінки. Комісійний розгляд сприятиме об'єктивному оцінювання та прийняттю рішень, гарантуванню прав посадових осіб дипломатичної служби, зміцненню їх мотивації до розвитку. Важливого значення має виважений підхід до врегулювання статусу такої комісії, особливостей її організації з урахуванням специфіки дипломатичної служби, включення до неї представників громадськості. У статті підкреслено, що запровадження комісійного оцінювання у дипломатичній службі не вирішить всіх проблем у цій сфері та має бути доповнене комплексом інших заходів, одним із яких повинен стати перегляд наслідків виставлення тих чи інших оцінок.

Ключові слова: оцінювання, дипломатична служба, державна служба.

\section{Summary}

Fedchyshyn S. A. Evaluation of results of performance of officials of diplomatic service of Ukraine: suggestions for improvement. - Article.

The article is devoted to the evaluation of the results of performance of officials of the diplomatic service of Ukraine. It is emphasized that the evaluation of the results of performance is an important institution, on the proper organization and legal regulation of which depends the provision of professionalism and efficiency of the diplomatic service of Ukraine. The current state of legal regulation of evaluation of diplomatic service officials is analyzed. Attention is drawn to some inconsistencies in the provisions of the laws of Ukraine "On Civil Service" and "On Diplomatic Service". It is necessary to amend the resolution of the Cabinet of Ministers of Ukraine "On approval of the Procedure of evaluation of the performance of civil servants" from 23.08.2017 and settle it within a separate section on the evaluation of performance of officials of the diplomatic service. It is emphasized that improving of the evaluation of the results of the performance of the diplomatic service officials the best foreign experience should be taken into account. It is concluded that a possible way to improve this institution may be the introduction of additional evaluation by the commission of those officials of the diplomatic service who received excellent or negative grades. The commission review will contribute to the objective evaluation and decision-making, guarantee the rights of officials of the diplomatic service, strengthen their motivation for development. It is important to take a balanced approach to regulating the status of such a commission, the peculiarities of its organization, taking into account the specifics of the diplomatic service of Ukraine, the inclusion of members of the public. It is outlined that the introduction of commission evaluation in the diplomatic service of Ukraine will not solve all problems in this sphere and should be supplemented by a set of other different measures, one of which should be to review the consequences of evaluation grades.

Key words: evaluation, diplomatic service, civil service. 